\title{
Effect of Foliar Nutrition on Growth, Yield Attributes and Seed Yield of Pulse Crops
}

\author{
M. Uma Maheswari", A. Karthik and R. Ajay Kumar \\ Department of Agronomy, Agricultural College and Research Institute, Coimbatore - 641003 , \\ Tamil Nadu Agricultural University, Tamil Nadu, India \\ *Corresponding author
}

A B S T R A C T

\begin{tabular}{|c|c|}
\hline Keywords & \\
\hline $\begin{array}{l}\text { Pulse crop, Foliar } \\
\text { nutrition, Di } \\
\text { Ammonium } \\
\text { Phosphate, Potash, } \\
\text { Seed yield. }\end{array}$ & $\begin{array}{l}\text { seed yield of pulse crop during rabi } 2013-14 \text {. The experiment was laid out in split plot } \\
\text { design and replicated thrice. The pulse crop viz., blackgram, greengram, cowpea and horse } \\
\text { gram were tried as treatments under main plot. Foliar nutrient sprays viz., } 2 \% \text { DAP, } 1 \% \\
\mathrm{KCL}, 1 \% \text { boron, } 1 \% \mathrm{MgSO}_{4}, 1 \% \mathrm{ZnSO}_{4} \text { and without foliar spray were fitted under sub }\end{array}$ \\
\hline Article Info & plant height, dry matter \\
\hline $\begin{array}{l}\text { Accepted: } \\
\text { 28 September } 2017 \\
\text { Available Online: } \\
\text { 10 November } 2017\end{array}$ & $\begin{array}{l}\text { production, and number pods plant , number of seeds plant , test grain weight, yield and } \\
\text { grain yield with foliar application of nutrients. Maximum grain yield was recorded with } \\
2 \% \text { DAP followed by } 1 \% \mathrm{KCl} \text { at flowering and } 15 \text { days later was the viable nutrient } \\
\text { management package for the pulses for getting higher income through higher productivity. }\end{array}$ \\
\hline
\end{tabular}

\section{Introduction}

Pulses occupy a unique position in Indian agriculture in virtue of the fact that they provide the rich source of vegetable protein and calories to the average Indian diet. Besides being a rich source of protein, they maintain soil fertility through biological nitrogen fixation in soil and thus play a vital role in sustainable agriculture (Balusamy and Meyyazhagan, 2000). India is the largest producer and consumer of pulses in the world accounting for 33.6 percent of the world area and 24 percent of the world production of pulses (Pramanik, 2009). The area under pulse crop is increasing continuously but productivity is decreasing year by year. The reasons for decreasing productivity are due to decreasing soil fertility especially macro and micronutrients, imbalanced use of fertilizer and occurrences of physiological disorders such as inefficient partitioning of assimilates, poor pod setting, excessive flower abscission and lack of nutrients during the critical stages of crop growth leads to nutrient stress, poor growth and productivity were found to be some of the yield barriers of pulse crop (Ali et al., 2010). Nutrients are more important because in pulse crop to synchronized flowering altered the source-sink relationship due to rapid translocation of nutrients from leaves to the developing pods. To overcome these constraints, additional nutrition through foliar feeding is play a vital role in pulse production by stimulating root development, nodulation, energy transformation, various 
metabolic processes and increasing pod setting and thereby increasing the yield (Ravisankar et al., 2003). Foliar spray is one of the most efficient ways of supplying essential nutrients to a growing crop. Considering the above facts the experiment was conducted to incredulous this problem by foliar feeding of nutrients.

\section{Materials and Methods}

The field experiment was conducted during Rabi 2013-14 at College of Agricultural Technology, Kullapuram, Theni situated in the Southern agro climatic zone of Tamil Nadu at $10^{\circ} 5^{\prime}$ North latitude and $77^{\circ} 5^{\prime}$ ' East longitude at an altitude of $40 \mathrm{~m}$ above mean sea level. The soil of the experimental field was sandy clay loam in texture with the available nitrogen $234.26 \mathrm{~kg} \mathrm{ha}^{-1}$, phosphorus $16.76 \mathrm{~kg} \mathrm{ha}^{-1}$, potassium $294.24 \mathrm{~kg} \mathrm{ha}^{-1}$ and organic carbon content $0.30 \%$. The experiment was laid out in split plot design and replicated thrice, assigning pulse crops (Blackgram $\left(\mathrm{M}_{1}\right)$, Greengram $\left(\mathrm{M}_{2}\right)$, Cowpea $\left(\mathrm{M}_{3}\right)$ and Horse gram $\left(\mathrm{M}_{4}\right)$ to main plots and foliar nutrients spray (2\% DAP $\left(\mathrm{S}_{1}\right), 1 \%$ $\operatorname{KCL}\left(\mathrm{S}_{2}\right), 1 \%$ boron $\left(\mathrm{S}_{3}\right), 1 \% \mathrm{MgSO}_{4}\left(\mathrm{~S}_{4}\right), 1$ $\% \mathrm{ZnSO}_{4}\left(\mathrm{~S}_{5}\right)$ and without foliar spray $\left(\mathrm{S}_{5}\right)$ as sub plot treatments. Local variety seeds of green gram, black gram, cowpea and horse gram with germination of 93 per cent was used at the rate of $20 \mathrm{~kg} \mathrm{ha}^{-1}$. The seeds were treated with Rhizobium culture half an hour before sowing. The treated seeds were sown at $30 \mathrm{~cm}$ between rows and $10 \mathrm{~cm}$ between seed to seed to maintain optimum plant population. The recommended fertilizer dose of $25 \mathrm{~kg} \mathrm{~N}, 50 \mathrm{~kg} \mathrm{P}_{2} \mathrm{O}_{5}, 25 \mathrm{~kg} \mathrm{~K}_{2} \mathrm{O}$ ha $^{-1}$ were applied as basal through urea, single super phosphate and muriate of potash in lines and incorporated at the time of sowing. Foliar application was done at flowering and pod filling stages of crop growth using high volume sprayer with a spray volume of 500 litre $\mathrm{ha}^{-1}$. Recommended crop management practices including plant protection remained common to all the treatments. The data collected for pulse crops were statistically analyzed following the procedure given by Gomez and Gomez (2010). Whenever significant difference existed, critical difference was constructed at five per cent probability level. Such of those treatments where the difference are not significant were denoted as NS.

\section{Results and Discussion}

\section{Growth characters}

The foliar application of $2 \%$ DAP produced significantly increased the plant height and number of branches plant ${ }^{-1}$ in black gram, greengram, cowpea and horse gram which was statistically on par with spray of $1 \% \mathrm{KCl}$ and $1 \%$ boron. This might be due to enhanced level of nutrient available in the rhizo-ecosystem of the foliar applied nutrients resulting in better plant growth and development. Application of nutrients would have resulted in better vegetative growth as observed by taller plants, more branches and efficient nodulation. This favourable influence of foliar application of nutrients could be ascribed to more and quick access to nutrients by plants at seedling and early development stages (Nawange et al., 2011). The leaf area index and dry matter production was increased with the foliar nutrition of $2 \%$ DAP and it was comparable with foliar spray of $1 \% \mathrm{KCl}$ and $1 \%$ boron at flowering and pod setting stage of pulse crop (Table 1.). This might be due to increased availability of nutrients to plants leading to maximum plant growth in terms of plant height and leaf area which in turn contributed higher dry matter production. Results of this study also confirmed the findings of Nazir Hussain et al., (2011). Foliar application of nutrients is a well-established tool to complete and to enrich plant nutrition. 
Table.1 Effect of foliar nutrition on growth characters of pulse crops

\begin{tabular}{|c|c|c|c|c|c|c|c|c|c|c|c|c|c|c|}
\hline \multirow{2}{*}{ Treatment } & \multicolumn{7}{|c|}{ Plant height $(\mathrm{cm})$} & \multicolumn{7}{|c|}{ Number of branches plant $^{-1}$} \\
\hline & $\mathbf{S}_{1}$ & $\mathbf{S}_{\mathbf{2}}$ & $\mathbf{S}_{\mathbf{3}}$ & $\mathbf{S}_{\mathbf{4}}$ & $\mathbf{S}_{5}$ & $\mathbf{S}_{6}$ & Mean & $\mathbf{S}_{\mathbf{1}}$ & $\mathbf{S}_{\mathbf{2}}$ & $\mathbf{S}_{\mathbf{3}}$ & $\mathbf{S}_{\mathbf{4}}$ & $\mathbf{S}_{5}$ & $S_{6}$ & Mean \\
\hline $\mathbf{M}_{1}$ & 42.27 & 42.09 & 41.67 & 40.20 & 40.70 & 39.03 & 40.99 & 46.54 & 45.79 & 45.13 & 44.13 & 44.16 & 43.17 & 44.82 \\
\hline $\mathbf{M}_{2}$ & 50.10 & 47.80 & 46.77 & 48.47 & 49.70 & 48.33 & 48.53 & 53.54 & 50.87 & 50.98 & 52.57 & 53.24 & 52.54 & 52.29 \\
\hline $\mathbf{M}_{3}$ & 74.77 & 69.54 & 69.63 & 69.60 & 68.43 & 63.63 & 69.27 & 76.50 & 72.83 & 72.80 & 72.83 & 71.87 & 67.17 & 72.33 \\
\hline $\mathbf{M}_{4}$ & 71.03 & 65.40 & 63.97 & 60.93 & 62.43 & 55.30 & 63.18 & 74.50 & 68.54 & 67.50 & 64.20 & 65.80 & 57.87 & 66.40 \\
\hline \multirow[t]{2}{*}{ Mean } & 59.54 & 56.21 & 55.51 & 54.80 & 55.32 & 51.58 & & 62.77 & 59.51 & 59.10 & 58.44 & 58.77 & 55.19 & \\
\hline & $\mathbf{M}$ & $\mathbf{S}$ & $S$ at $M$ & & & & & $\mathbf{M}$ & $\mathbf{S}$ & $S$ at $M$ & & & & \\
\hline SEd & 0.97 & 1.60 & 3.22 & & & & & 1.14 & 1.38 & 2.77 & & & & \\
\hline $\mathrm{CD}(\mathrm{P}=0.05)$ & 2.20 & 1.70 & 3.40 & & & & & 2.78 & 2.80 & 5.59 & & & & \\
\hline \multirow{2}{*}{ Treatment } & \multicolumn{7}{|c|}{ Leaf area index (LAI) } & \multicolumn{7}{|c|}{ Dry matter production (g plant- ${ }^{\mathbf{1}}$ ) } \\
\hline & $\mathbf{S}_{1}$ & $\mathbf{S}_{\mathbf{2}}$ & $\mathbf{S}_{\mathbf{3}}$ & $\mathbf{S}_{\mathbf{4}}$ & $\mathbf{S}_{\mathbf{5}}$ & $\mathbf{S}_{6}$ & Mean & $\mathbf{S}_{1}$ & $\mathbf{S}_{2}$ & $\mathbf{S}_{\mathbf{3}}$ & $\mathbf{S}_{\mathbf{4}}$ & $\mathbf{S}_{\mathbf{5}}$ & $\mathbf{S}_{6}$ & Mean \\
\hline $\mathbf{M}_{1}$ & 0.8 & 0.6 & 0.6 & 0.7 & 0.6 & 0.4 & 0.6 & 81.57 & 80.28 & 73.20 & 70.87 & 81.91 & 64.20 & 75.34 \\
\hline $\mathbf{M}_{2}$ & 0.9 & 0.7 & 0.6 & 0.6 & 0.5 & 0.5 & 0.6 & 89.91 & 78.61 & 74.28 & 70.17 & 77.91 & 64.83 & 75.95 \\
\hline $\mathbf{M}_{3}$ & 1.7 & 0.9 & 0.9 & 0.8 & 0.9 & 0.7 & 1.0 & 101.50 & 95.20 & 91.83 & 82.20 & 73.94 & 66.24 & 85.15 \\
\hline $\mathbf{M}_{4}$ & 1.0 & 0.8 & 0.7 & 0.6 & 0.7 & 0.6 & 0.7 & 92.83 & 89.62 & 82.83 & 75.50 & 86.57 & 67.83 & 82.53 \\
\hline \multirow[t]{2}{*}{ Mean } & 1.1 & 0.8 & $\mathbf{0 . 7}$ & $\mathbf{0 . 7}$ & 0.7 & 0.5 & & 91.45 & 85.93 & 80.54 & 74.69 & 80.08 & 65.78 & \\
\hline & $\mathbf{M}$ & $\mathbf{S}$ & S at $M$ & & & & & $\mathbf{M}$ & $\mathbf{S}$ & $\mathbf{S}$ at $\mathrm{M}$ & & & & \\
\hline SEd & 0.020 & 0.027 & 0.054 & & & & & 1.038 & 1.396 & 2.793 & & & & \\
\hline $\mathrm{CD}(\mathrm{P}=0.05)$ & 0.076 & 0.054 & 0.147 & & & & & 2.542 & 2.823 & 5.646 & & & & \\
\hline
\end{tabular}

Main plot : Pulse crops

$\mathrm{M}_{1}$ : Black gram

$\mathrm{M}_{2}$ : Green gram

$\mathrm{M}_{3}$ : Cowpea

$\mathrm{M}_{4}$ : Horse gram
Sub plot : Foliar nutrition at 30 and 45 DAS

$$
\begin{aligned}
& \mathbf{S}_{1}: 2 \% \text { DAP } \\
& \mathrm{S}_{2}: 1 \% \mathrm{Kcl} \\
& \mathrm{S}_{3}: 1 \% \text { Boron } \\
& \mathrm{S}_{4}: 1 \% \text { Magnesium Sulphate } \\
& \mathrm{S}_{5}: 1 \% \text { Zinc Sulphate } \\
& \mathrm{S}_{6}: \text { Control (No foliar spray) }
\end{aligned}
$$


Table.2 Effect of foliar nutrition on yield attributes and seed yield of pulse crops

\begin{tabular}{|c|c|c|c|c|c|}
\hline Treatment & $\begin{array}{c}\mathbf{5 0 \%} \text { flowering } \\
\text { (Days) }\end{array}$ & $\begin{array}{l}\text { Number of } \\
\text { pods plant }^{-1}\end{array}$ & $\begin{array}{l}\begin{array}{l}\text { Number of } \\
\text { seeds pod }^{-1}\end{array} \\
\end{array}$ & $\begin{array}{l}\text { Test grain } \\
\text { weight (g) }\end{array}$ & $\begin{array}{c}\text { Seed yield } \\
\left(\mathrm{kg} \mathrm{ha}^{-1}\right)\end{array}$ \\
\hline $\mathbf{M}_{1}$ & 53.60 & 29.10 & 20.00 & 596 & 16695 \\
\hline $\mathbf{M}_{2}$ & 43.50 & 27.60 & 19.30 & 584 & 16065 \\
\hline $\mathbf{M}_{3}$ & 39.90 & 25.90 & 18.90 & 507 & 12215 \\
\hline $\mathbf{M}_{4}$ & 39.70 & 25.50 & 18.80 & 453 & 10305 \\
\hline SEd & 0.25 & 0.95 & 0.15 & 12 & - \\
\hline $\mathrm{CD}(\mathbf{P}=0.05)$ & 0.63 & 0.23 & 0.37 & 29 & - \\
\hline $\mathrm{S}_{1}$ & 51.30 & 28.90 & 19.90 & 599 & 17022 \\
\hline $\mathbf{S}_{2}$ & 45.30 & 27.40 & 19.20 & 529 & 12749 \\
\hline $\mathbf{S}_{\mathbf{3}}$ & 44.90 & 27.00 & 19.00 & 511 & 12735 \\
\hline $\mathbf{S}_{4}$ & 52.40 & 29.40 & 20.00 & 612 & 16697 \\
\hline $\mathbf{S}_{\mathbf{5}}$ & 27.10 & 22.60 & 19.30 & 423 & 9900 \\
\hline$S_{6}$ & 132 & 11321 & 132 & 132 & 56 \\
\hline SEd & 0.90 & 0.61 & 0.10 & 13 & - \\
\hline $\mathrm{CD}(\mathrm{P}=0.05)$ & 1.84 & 1.23 & 0.20 & 25 & - \\
\hline \multicolumn{6}{|c|}{$M$ at $S$} \\
\hline SEd & 1.64 & 1.08 & 0.23 & 25 & - \\
\hline $\mathrm{CD}(\mathrm{P}=0.05)$ & 3.36 & 2.12 & 0.52 & 54 & - \\
\hline \multicolumn{6}{|c|}{ S at $M$} \\
\hline SEd & 1.81 & 1.22 & 0.20 & 25 & - \\
\hline $\mathrm{CD}(\mathrm{P}=\mathbf{0 . 0 5})$ & 3.69 & 2.46 & 0.41 & 51 & - \\
\hline
\end{tabular}

Main plot : Pulse crop

$\begin{array}{lll}M_{1}: & \text { Black gram } \\ M_{2}: & \text { Green gram } \\ M_{3}: & \text { Cowpea } \\ M_{4}: & \text { Horse gram }\end{array}$

Sub plot : Foliar nutrition at 30 and 45 DAS

$$
\begin{array}{ll}
\mathrm{S}_{1} & : 2 \% \mathrm{DAP} \\
\mathrm{S}_{2} & : 1 \% \mathrm{Kcl} \\
\mathrm{S}_{3}: & 1 \% \text { Boron } \\
\mathrm{S}_{4}: & 1 \% \text { Magnesium Sulphate } \\
\mathrm{S}_{5}: & 1 \% \text { Zinc Sulphate } \\
\mathrm{S}_{6}: \text { Control (No foliar spray) }
\end{array}
$$

Foliar feeding can provide the nutrients needed for normal growth and development of crops in cases where absorption of nutrients from the soil is disturbed. As uptake of nutrients through the foliage is considerably faster than through roots, foliar sprays is the method of choice when prompt correction of nutrient deficiencies is required.

\section{Yield attributes}

Days to attain $50 \%$ flowering were significantly delayed with increasing levels of foliar nutrients. The possible reason might be that supply of nitrogen and other nutrients are associated with protein synthesis consequently material needed for the formation of fruiting body remains scarce. To fulfil the gap, metabolism remains engaged in cell division, elongation and multiplication for vegetative growth for a longer period and thus there was a delay in the flowering (Dixit et al., 2008). Foliar spray of $2 \%$ DAP recorded the highest values for yield attributing characters viz., number of pods plant $^{-1}$, number of seeds pod ${ }^{-1}$, pod length and 
test grain weight than other foliar spray treatments (Table 2). The increase in yield attributes might be due to supplementation of nutrients at the critical stage without physiological stress. Foliar application of nutrients enhanced the number of floral buds, prevented the floral shedding by maintaining optimum bio-physiological conditions in plants. Adequate and continuous nutrient availability through soil and foliar nutrition promotes the supply of assimilates to sink or yield container, thus enlarging the size of the yield structure. The findings of Hamayun et al., (2002) have also confirmed the results of present study.

\section{Grain yield}

The foliar application of $2 \%$ DAP produced significantly increased the grain yield in black gram, greengram, cowpea and horse gram which was statistically on par with spray of 1 $\% \mathrm{KCl}$ and $1 \%$ boron (Table 2). The impact of the foliar nutrients to meet the nutrient demand of the crop at the critical stage onsite, where they are needed without stress, would have resulted in better growth and development of the crop and ultimately the yield attributing characters and yield on one hand. The balanced growth habit, which induced more flower and fruiting body production with timely supply of nutrients through foliar spray might have reduced shedding of flowers and fruits, which led to a positive source-sink gradient of photosynthates translocation due to growth regulator on the other hand. These favourable effects might have attributed for higher yield of green gram, black gram, cowpea and horse gram under the foliar spray of nutrients and growth regulators. This finding is in line with the results of Manivannan et al., (2003).

The present study indicated that foliar application of $2 \%$ DAP resulted in higher grain yield in black gram, greengram, cowpea and horse gram which was followed by $1 \%$ $\mathrm{KCl}$ spray. The growth parameters and yield attributes were also found to be higher when $2 \%$ DAP is given as spray at flowering and pod filling stages. This may be due to balanced growth habit, which induced more flower and fruiting body production with timely supply of nutrients through foliar spray might have reduced shedding of flowers and fruits, which led to a positive source-sink gradient of photosynthates translocation due to growth regulator. Hence, foliar application of $2 \%$ DAP or $1 \% \mathrm{KCl}$ will be viable and feasible option inorder to get higher yield in pulse crops.

\section{References}

Ali, M.A., G. Abbas, Q. Mohy-ud-Din, K. Ullah, G. Abbas and M. Aslam. 2010. Response of mungbean (Vigna radiata L.) to phosphatic fertilizer under arid climate. J. Animal \& Plant Sci., 20(2): 83-86.

Balusamy, M. and Meyyazhagan. 2000. Foliar nutrition to pulse crop. In: Proc. Symp. On recent advances in pulse up production technology, TNAU, Coimbatore.

Dixit, P.M., S. Elamathi, Zade Kishor Kishanrao and Neeta Choubey. 2008. Effect of foliar application of nutrients and NAA in mungbean. J. Food Legume, 21(4): 277-278.

Gomez, K.A and A.A. Gomez. 2010. Statistical procedures for agricultural research. ( $2^{\text {nd }}$ Ed.), Wiley India Pvt Ltd., India.

Manivannan, V., K. Thanunathan, V. Imayavaramban and N. Ramanathan. 2003. Growth and growth analysis of rice fallow blackgram as influenced by foliar application of nutrients with and without Rhizobium seed inoculation. Legume Res., 26(4): 296-299. 
Muhammad Hussain, Shamshad Hussain Shah and M. Shafi Nazir. 2002. Differential genotypic response to phosphorus application in lentil (Lens culinaris Medic). Int. J. Agric. and Biol., 4(1): 61-63.

Nawange, D.D., A.S. Yadav and R.V. Singh. 2011. Effect of phosphorus and sulphur application on growth, yield attributes and yield of chickpea (Cicer arietinum L). Legume Res., 34(1): 48-50.

Nazir Hussain, Mohammad Mehdi and Rehana Habib Kant. 2011. Response of nitrogen and phosphorus on growth and yield attributes of blackgram (Vigna mungo L.). Res. J. Agric. Sci., 2(2): 334-336.

Pramanik, S.C. 2009. Rainwater management techniques for successful production of pulses in rainfed areas. Indian farming, 58(12): 15-18.

Ravisankar, N., B. Chandrasekharan, K. Sathiyamoorthi and T.N. Balasubramanian. 2003. Effect of agronomic practices for multiblooming in greengram (Vigna radiata L.) (cv. Pusa bold). Madras agric. J., 90(1-3): 166-169.

\section{How to cite this article:}

Uma Maheswari, M., A. Karthik and Ajay Kumar, R. 2017. Effect of Foliar Nutrition on Growth, Yield Attributes and Seed Yield of Pulse Crops. Int.J.Curr.Microbiol.App.Sci. 6(11): 4134-4139. doi: https://doi.org/10.20546/ijcmas.2017.611.484 